\title{
Evaluation of Recommended Methods for Radioisotope Red Cell Survival Studies
}

\author{
Tatsum Uchida, Shigeo Kariyone, Masahiro Miki, ${ }^{*}$ \\ Michtaki Sato, $\dagger$ Katsuhiko Fujtmori $\dagger$ and Kotoko \\ NakaJima $\dagger$ \\ *The First Division of Internal Medicine, Fukushima Prefectural \\ Medical College, Fukushima, *The First Division of Internal \\ Medicine, Faculty of Medicine, Kyoto University, Kyoto, and \\ †Central Radioisotope Clinic, Kyoto University Hospital, Kyoto
}

Uchida, T., Kariyone, S., Miki, M., Sato, M., Fujimori, K. and Nakajima, K. Evaluation of Reconmended Methods for Radioisotope Red Cell Survival Studies. Tohoku J. exp. Med., 1976, 120 (3), 219-223 _ Mean red cell life-span in normal subjects and in patients with various hematological disorders was examined with ${ }^{51} \mathrm{Cr}$ and $\mathrm{DF}^{32} \mathrm{P}$. The results with ${ }^{51} \mathrm{Cr}$ were corrected for ${ }^{51} \mathrm{Cr}$ elution using correction factors. The results by the two methods agreed fairly well with each other. Elution rate in various hematological disorders was $2.3 \%$ per day or less except for the patients with extracorpuscular hemolytic agents such as autoimmune hemolytic anemia or congestive splenomegaly. It is concluded that estimates of mean red cell life-span by corrected ${ }^{51} \mathrm{Cr}$ method are more useful and sufficient than uncorrected ${ }^{51} \mathrm{Cr}$ or $\mathrm{DF}^{32} \mathrm{P}$ method in general hematological disorders. $\longrightarrow$ mean red cell life span; corrected ${ }^{51} \mathrm{Cr}$ method; elution rates; $\mathrm{DF}^{32} \mathrm{P}$ method

Red cell survival studies with radioactive chromate $\left({ }^{51} \mathrm{Cr}\right)$ are widely used in clinical hematology. The elution of ${ }^{51} \mathrm{Cr}$ from intact cells has raised difficulties in the interpretation of survival studies. The International Committee for Standardization in Hematology (ICSH, 1971) recommended the methods for radioisotope red cell survival studies, in which mean red cell life-span (MCL) was estimated. The present study was undertaken to evaluate this method by tagging red cells simultaneously with ${ }^{51} \mathrm{Cr}$ and diisopropylfluorophosphate $\left(\mathrm{DF}^{32} \mathrm{P}\right)$ in various hematological disorders, and comparing the MCL by both methods. The elution rate of ${ }^{51 \mathrm{Cr}}$ from red cells in each hematological disorder is also presented here.

\section{MeTHODs}

The red cell life-span was measured with ${ }^{51} \mathrm{Cr}$ and $\mathrm{DF}^{32} \mathrm{P}$ simultaneously in 54 patients with normal routine hematological laboratory data and various hematological disorders. Labeling was carried out according to the methods recommended by IOSH (1971). Twenty $\mathrm{ml}$ of venous blood were obtained in a plastic syringe containing $3.0 \mathrm{ml}$

Received for publication, May 15, 1976.

Reprint request: Tatsumi Uchida, M.D., The First Division of Internal Medicine, Fukushima Prefectural Medical College, 4-45, Sugizuma-cho, Fukushima 960, Japan. 
of NIH formula " $A$ " acid-citrate-dextrose (ACD) and transfused into the vial. Radioactive sodium chromate solution $\left({ }^{51} \mathrm{Cr}: 1.5 \mu \mathrm{Ci} / \mathrm{kg}\right.$ body weight) was added and the mixture was incubated for $30 \mathrm{~min}$ at $37^{\circ} \mathrm{C}$. Fifty $\mathrm{mg}$ of ascorbic acid were added to the vial and a $20 \mathrm{ml}$ aliquot of the labeled red cell suspension was removed for re-infusion into the subjects. At $30 \mathrm{~min}$ after the completion of the infusion, $5 \mathrm{ml}$ of blood specimen were taken. Duplicate $2 \mathrm{ml}$ blood samples were washed with physiologic saline and the supernatant was discarded.

Further samples per week were taken until four weeks after the infusion. The radioactivity of each sample was measured in an antomatic well-type scintillation counter (Nuclear Chicago, Chicago, Ill.). $T_{50} \mathrm{Cr}$ was determined from the time for the radioactivity of ${ }^{51} \mathrm{Cr}$ in the circulation to fall to $50 \%$ of its initial value. In the calculation of $\mathrm{MCL}$, all ${ }^{51} \mathrm{Cr}$ measurements were corrected for elution according to the tables of correction factors (ICSH, 1971). The data were plotted on linear and semilogarithmic graph paper. If a straight line could be fitted to the data points, the line was obtained accarding to the method of least squares, MCL was estimated directly from linear disappearance curves by extrapolating to zero activity. If an exponential disappearance curve was obtained, MCL was calculated from the half-time divided by the natural logarithm of 2 .

$D^{32} P$ (Radiochemical Centre, Amersham, England) in sterile propylene glycol was dissolved in $20 \mathrm{ml}$ of saline and administered intravenously. The amount of DFP injected was not greater than $0.02 \mathrm{mg} / \mathrm{kg}$ body weight, and the radioactivity injected did not exceed $0.7 \mu \mathrm{Ci} / \mathrm{kg}$ body weight. One $\mathrm{ml}$ of blood sample was taken at $24 \mathrm{hr}$ and thereafter at least two specimens per week for the duration of the study. Red cell ${ }^{32} \mathrm{P}$ radioactivity was measured by a gas-flow counter equipped with an automatic sample changer (Model 181A decade scaler: Nuclear Chicago). Presentation of red cell survival data was the same as the calculation of MCL by ${ }^{51 C r}$ method.

The \% chromium elution rate was calculated by Cline's method (Cline and Berlin 1963). If the data points show a straight line, and if the elution of ${ }^{51} \mathrm{Cr}$ from intact cell is exponential, then

$$
N=N_{0}\left(1-\frac{t}{T}\right) e^{-K_{e} t},
$$

where $N$ is the ${ }^{51} \mathrm{Cr}$ counts per $\mathrm{min} / \mathrm{ml}$ of red cell at any time " $t$ " and $N_{0}$ is the ${ }^{51} \mathrm{Cr}$ counts per min/ml of red cell at time zero. $T$ is the MCL, $T^{\prime}$ is the $T_{50} \mathrm{Cr}$ and $K_{e}$ is the chromium elution rate constant. If MCL and $T_{50} \mathrm{Cr}$ are known from simultaneous

TABLE 1. Average values of mean red cell life-span

\begin{tabular}{|c|c|c|c|c|}
\hline & \multirow{2}{*}{$\begin{array}{c}\text { Number } \\
\text { of } \\
\text { cases }\end{array}$} & \multicolumn{3}{|c|}{ Hematological data } \\
\hline & & $\operatorname{RBC}\left(\times 10^{4} / \mu 1\right)$ & $\mathrm{Hb}(\mathrm{g} / 100 \mathrm{ml})$ & $\mathrm{Ht}(\%)$ \\
\hline $\begin{array}{l}\text { Hematologically } \\
\text { normal subjects }\end{array}$ & 12 & $486.3 \pm 45.8$ & $14.5 \pm 1.7$ & $44.5 \pm 2.6$ \\
\hline $\begin{array}{l}\text { Iron deficiency } \\
\text { anemia }\end{array}$ & 10 & $304.4 \pm 51.0$ & 6. $7 \pm 1.2$ & $25.3 \pm 4.6$ \\
\hline $\begin{array}{l}\text { Hereditary } \\
\text { spherocytosis }\end{array}$ & 4 & $300.8 \pm 42.8$ & $10.0 \pm 0.7$ & $28.8 \pm 4.9$ \\
\hline $\begin{array}{l}\text { Autoimmune } \\
\text { hemolytic anemia }\end{array}$ & 4 & $271.5 \pm 10.0$ & $9.6 \pm 1.7$ & $28.0 \pm 4.5$ \\
\hline Aplastic anemia & 5 & $250.6 \pm 63.8$ & $7.0 \pm 3.0$ & $27.0 \pm 7.4$ \\
\hline $\begin{array}{l}\text { Congestive } \\
\text { splenomegaly }\end{array}$ & 6 & $372.7 \pm 40.8$ & $10.5 \pm 0.7$ & $32.2 \pm 5.1$ \\
\hline $\begin{array}{l}\text { Acute leukemia \& } \\
\text { lymphoma }\end{array}$ & 6 & $246.0 \pm 100.6$ & $7.0 \pm 3.6$ & $22.2 \pm 9.8$ \\
\hline $\begin{array}{l}\text { Myeloproliferative } \\
\text { disorders }\end{array}$ & 5 & $543.6 \pm 161.6$ & $15.6 \pm 4.6$ & $45.8 \pm 13.2$ \\
\hline $\begin{array}{l}\text { Idiopathic thrombo- } \\
\text { cytopenic purpura }\end{array}$ & 2 & $403.0 \pm 3.0$ & $12.8 \pm 0.6$ & $40.5 \pm 1.5$ \\
\hline
\end{tabular}

Mean \pm s.D. * Significantly higher values than normal $(p<0.01)$ 
measurement of red cell survival with $D F^{32} \mathrm{P}$ and ${ }^{51} \mathrm{Cr}$, then $K_{e}$ can be determined as follows:

$$
K_{0}=\frac{\ln 2+\ln \left(1-\frac{T^{\prime}}{T}\right)}{T^{\prime}}
$$

If the red cell disappearance curve shows exponential fashion, then

$$
N=N_{0} e^{-\left\{K_{d}+K_{e}\right) t}
$$

where $K_{d}$ is the rate of random destruction of red cells. In DF ${ }^{32} \mathrm{P}$ labeling method, declining equation may be expressed by

$$
N^{\prime}=N_{0}{ }^{\prime} e^{-K_{d}{ }^{t}} \text {, }
$$

where $N^{\prime}$ and $N_{0}^{\prime}$ are the counts per $\mathrm{min} / \mathrm{ml}$ of red cells with DF'P at any time " $t$ " and extrapolated from the declining portion to time zero, respectively. Then,

$$
K_{e}=\frac{\ln 2}{T^{\prime}}-\frac{1}{T}
$$

\section{Results}

The values for MCL and elution rates in 54 patients with various hematological disorders are shown in Table 1 . The mean value obtained by the corrected ${ }^{51} \mathrm{Cr}$ method in hematologically normal subjects was $102.1 \pm 10.8$ days (mean \pm s.D.) and that of $\mathrm{DF}^{32} \mathrm{P}$ method was $111.3 \pm 9.1$ days. The chromium elution rate calculated from simultaneous $\mathrm{DF}^{32} \mathrm{P}$ measurements in this group was $1.44 \pm 0.18$ $\%$. The elution rates in patients with iron deficiency anemia, hereditary

\begin{tabular}{|c|c|c|c|}
\hline \multicolumn{2}{|c|}{ "Licr method } & \multirow{2}{*}{$\begin{array}{l}\text { DF }{ }^{32} \mathrm{P} \text { method } \\
\text { MCL (days) }\end{array}$} & \multirow{2}{*}{$\begin{array}{l}\text { Elution rate } \\
\% \text { per day }\end{array}$} \\
\hline$T_{50} \mathrm{Cr}$ (days) & MOL (days) & & \\
\hline $28.0 \pm 2.5$ & $102.1 \pm 10.8$ & $111.3 \pm 9.1$ & $1.44 \pm 0.18$ \\
\hline $23.4 \pm 2.6$ & $82.1 \pm 13.0$ & $66.2 \pm 10.1$ & 1. $13 \pm 0.57$ \\
\hline $11.4 \pm 2.4$ & $41.0 \pm 9.2$ & $25.5 \pm 4.7$ & 1. $22 \pm 0.13$ \\
\hline $6.0 \pm 1.1$ & $20.6 \pm 4.5$ & $20.7 \pm 7.3$ & 5. $31 \pm 2.62^{*}$ \\
\hline $12.9 \pm 4.3$ & $49.9 \pm 12.1$ & $31.2 \pm 8.7$ & $0.66 \pm 0.47$ \\
\hline $20.8 \pm 4.3$ & $74.3 \pm 19.7$ & $74.8 \pm 21.8$ & 2. $14 \pm 0.77^{*}$ \\
\hline $16.5 \pm 7.5$ & $63.9 \pm 24.1$ & $49.0 \pm 30.3$ & $1.21 \pm 0.50$ \\
\hline $26.1 \pm 5.0$ & $96.0 \pm 17.7$ & $82.6 \pm 28.5$ & $1.10 \pm 0.24$ \\
\hline $20.3 \pm 1.8$ & $73.0 \pm 10.0$ & $74.8 \pm 14.8$ & $1.82 \pm 0.08$ \\
\hline
\end{tabular}
spherocytosis, autoimmune hemolytic anemia, aplastic anemia, congestive splenomegaly, lymphoma and leukemia, myeloproliferative disorders and idiopathic thrombocytopenic purpura were $1.13 \pm 0.57,1.22 \pm 0.13,5.31 \pm 2.62,0.66 \pm 0.47$, 
$2.14 \pm 0.77,1.21 \pm 0.50,1.10 \pm 0.24$ and $1.82 \pm 0.08$, respectively. The range of elution rates in various hematological disorders was $0.13-2.32 \%$ per day except for autoimmune hemolytic anemia $(0-8.00 \%$ per day) and congestive splenomegaly (1.04 $-3.40 \%$ per day), which were significantly higher than normal value. There was a positive correlation between MCL obtained by $\mathrm{DF}^{32} \mathrm{P}$ and corrected ${ }^{51} \mathrm{Cr}$ methods in hematologically normal subjects $(r=0.704, p<0.01)$. The similar positive correlation was obtained between them in the entire group $(r=0.868, p<0.01)$.

\section{DISCUSSTON}

Radioactive sodium chromate has been widely used for red cell survival studies. The standardized method and MCL obtained by correction factors of ICSH (1971) are very convenient for quantitative measurement of red cell destruction. $\mathrm{DF}^{32} \mathrm{P}$ is a satisfactory label, because it is not eluted from the red cells at least after the first $24 \mathrm{hr}$ (Hjort et al. 1960) and MCL obtained by DF ${ }^{32} \mathrm{P}$ is thought to express the true life-span of red cells. We compared MCL obtained by corrected ${ }^{51} \mathrm{Cr}$ with that by $\mathrm{DF}^{32} \mathrm{P}$ techniques and evaluated the elution rates in various hematological disorders according to Cline's method (Cline and Berlin 1963). The mean values for MCL by corrected ${ }^{51} \mathrm{Cr}$ and $\mathrm{DF}^{32 \mathrm{P}}$ in hematological normal subjects were 102.1 and 111.3 days, respectively. These values agree with the results of Eernisse and Rood (1961) (121,126 and 127.5 days), Shirakawa (1967) (113.4 \pm 8.2 days) and Bentley et al. (1974) (DFP, 111.2 \pm 20.3 ; corrected $\mathrm{Cr}, 110.4 \pm 8.2$ days). The chromium elution rate in this group was $1.44 \%$, which is in accordance with generally accepted value (Garby and Mollison (1971), 1.19\%; ICSH (1971), 1.31\%). In various hematological disorders, Cline and Berlin (1963) demonstrated that elution rates ranged from 0.67 to $2.27 \%$ per day, and Garby and Mollison (1971) obtained the similar results (0.56 to $2.04 \%$ per day). Although the elution rate is considered to vary greatly in patients with hematological diseases, that in each disorder has not been determined yet. From the calculation of elution rates in 12 hematologically normal subjects and 42 patients with hematological disorders, we found that elution rate in each disorder is $2.3 \%$ per day or less except for autoimmune hemolytic anemia and congestive splenomegaly. These findings suggest that extracorpuscular hemolytic agents such as an attachment of autoantibody to red cell membrane or red cell sequestration in marked splenomegaly might relate to elution process from red cells.

MCL obtained by corrected ${ }^{51} \mathrm{Cr}$ method coincided fairly well with that of DF${ }^{32} \mathrm{P}$ method $(r=0.868, p<0.01)$. Therefore, it is convenient to express the red cell survival as MCL rather than the raw ${ }^{51} \mathrm{Cr}$ data $\left(T_{50} \mathrm{Cr}\right)$ in general cases. Other advantages of ${ }^{51} \mathrm{Cr}$ as the label in comparison with $\mathrm{DF}^{32} \mathrm{P}$ are that only small volume of blood need to be labeled, observation period is four weeks or less and sites of cell destruction can be detected by surface counting. However, DF ${ }^{32} \mathrm{P}$ should be used when a precise measurement of MCL is necessary, especialy in patients with autoimmune hemolytic anemia or congestive splenomegaly. It would be concluded that ${ }^{51} \mathrm{Cr}$ method is sufficient in general red cell survival studies. 


\section{References}

1) Bentley, S.A., Glass, H.I., Lewis, S.M. \& Szur, L. (1974) Elution correction in ${ }^{51} \mathrm{Cr}$ red cell sruvival studies. Brit. J. Haemat., 26, 179-184.

2) Cline, M.J. \& Berlin, N.I. (1963) The red cell chromium elution rate in patients with some hematologic diseases. Blood, 21, 63-69.

3) Eernisse, J.G. \& Rood, J.J. (1961) Erythrocyte survival-time determinations with the aid of $\mathrm{DF}^{32} \mathrm{P}$. Brit. J. Haemat., 7, 382-404.

4) Garby, L. \& Mollison, P.L. (1971) Deduction of mean red-cell life-span from ${ }^{51} \mathrm{Cr}$ survival curves. Brit. J. Haemat., 20, 527-536.

5) Hjort, P.F., Paputchis, H. \& Cheney, B. (1960) Labeling of red blood cells with radioactive diusopropylfuorophosphate $\left(\mathrm{DFP}^{32}\right)$ : evidence for an initial release of label. J. Lab. clin. Med., 55, 416-424.

6) The International Committee for Standardization in Hematology (ICSH) (1971) Recommended methods for radioisotpe red cell survival studies. Blood, 38, 378-386.

7) Shirakawa, A. (1967) Studies on the red cell lifespan in iron deficiency anemia. I. Clinical studies on the red cell lifespan in iron deficiency anemia. Jap. Arch. intern. Med. (Jap.), 14, 43-56. 